\title{
EARLY CHILDHOOD LITERACY
}

\section{Mainita Elisnawati, Warananingtyas Palupi, Nurul Kusuma Dewi}

Universitas Sebelas Maret

xxxxxx@mail.ac.id

\section{Article History}

accepted 09/07/2018

approved 01/08/2018

published 17/09/2018

\section{Keywords}

literacy, program, early childhood

\begin{abstract}
Nowdays, children prefer to do activities using electronic tools and less often culturally read. The importance of introduction and reading culture applied since early childhood is expected to make children a literate and broad-minded generation. Introduction and reading culture is done by the nearest child (parents and teachers). The purpose of this research is to know the literacy program conducted by Library and Archives Service in realizing the literacy of early childhood, as well as the supporting facilities provided for the implementation of the literacy program. This research was conducted in the Regional Library of Bantul Regency. This study uses a qualitative approach to case studies Forms of literacy programs for early childhood include: 1) Visits to the library and reading books, 2) Screening, 3) Writing workshop. The literacy program focuses on the introduction of pre-school pre-school literacy.
\end{abstract}

Social, Humanities, and Education Studies (SHEs): Conference Series https://jurnal.uns.ac.id/shes
p-ISSN 2620-9284 e-ISSN 2620-9292 


\section{PENDAHULUAN}

PAUD adalah pendidikan yang memfasilitasi perkembangan dan pertumbuhan anak dan juga mengembangkan ragam potensi yang dimiliki. Morrison (2013) anak bisa disebut usia kritis, karena banyak potensi yang berkembang dan apabila tidak distimulasi dengan baik akan menimbulkan masalah dalam kehidupan selanjutnya. Literasi adalah kemampuan yang berkaitan dengan membaca, menulis, menyimak, dan berbicara. Sependapat dengan Reese (2000) bahwa pengalaman anak berinteraksi dengan literasi menyiapkan anak secara matang untuk mengikuti pembelajaran pada sekolah formal. Dapat disimpulakan bahwa PAUD merupakan fondasi dari pendidikan dan akan berkesinambungan terhadap pendidikan selanjutnya.

Minat baca masyarakat Indonesia tergolong masih rendah. Suyadi (2010) mengatakan bahwa indeks membaca masyarakat Indonesia hanya 0,001 yang artinya dari seribu penduduk hanya satu orang yang masih memiliki minat baca tinggi. Kabupaten Bantul sendiri hanya 3\% yang akrab dengan perpustakaan dan dari 345.368 kunjungan untuk anak usia dini hanya berkisar 2.880 merupakan fakta yang mengkhawatirkan. Berdasarkan data tersebut, pemerintah Kabupaten Bantul dalam hal ini Dinas Perpustakaan dan Kearsipan berupaya meningkatkan minat baca dan membudayakan baca pada masyarakat Kabupaten Bantul. Dinas Perpustakaan dan Kearsipan membuat program "OPERA MALAM BALI" yang merupakan singkatan dari Optimalisasi Peran Masyarakat Dalam Mewujudkan Bantul Literasi yang mana sasaran utamanya adalah masyarakat umum dan masyarakat sekolah. Program literasi tersebut bertujuan melahirkan generasi yang literat.

Berdasarkan pemaparan data diatas, peneliti memilih penelitian dengan locus di Dinas Perpustakaan dan Kearsipan dimana Dinas Perpustakaan berkomitmen untuk mempunyai program berkualitas, humanis, dan mampu mewujudkan literasi bagi anakanak pra sekolah di Kabupaten Bantul. Rumusan masalah dalam penelitian ini adalah bagaimana upaya Dinas Perpustakaan untuk membudayakan literasi dan bagaimana wujud pelaksanaannya dalam lapangan. Tujuan penelitian mendeskripsikan program dan kegiatan yang sudah berjalan dalam mewujudkan program literasi serta apa saja fasilitas pendukung program literasi.

Literasi berasal dari bahasa latin littera yang berarti huruf, pengertiannya melibatkan penguasaan sistem tulisan dan baca. Grambell \& Mazzoni (Beaty, 2013) mengkaji perkembangan anak tentang kemunculan literasi dengan berpendapat bahwa anak terlibat dalam berbagai perilaku kemunculan literasi, seperti mendengar cerita, membahas cerita, menyusun cerita, mencoretkan huruf, menuliskan nama. Abidin (2017) mengatakan masa perkembangan awal, literasi didefinisikan sebagai kemampuan mengungkapkan suatu bahasa dan gambar dalam bentuk membaca, menulis, berbicara, menyajikan, dan berpikir kritis.

Enggelbetus (2016) dalam penelitiannya mengemukakan bahwa literasi anak merupakan kemampuan yang berkaitan dengan, membaca, menulis, menyimak dan berbicara. Kern (2000) menambahkan bahwa literasi memerlukan setidaknya sebuah kepekaan yang tak terucap tentang hubungan-hubungan antara konvensi-konvensi tekstual dan konteks penggunaanya serta idealnya kemampuan untuk berefleksi secara kritis tentang hubungan-hubungan itu. Kemampuan literasi adalah landasan awal penguasaan ilmu pengetahuan, kemampuan awal dalam hal baca dan tulis. Cahyani (2015) mengatakan bahwa literasi awal bukan berarti diajarkan membaca langsung, namun terlebih dahulu menjadikan anak mencintai membaca, membangun fondasi untuk membaca. Susanto (2017) mengatakan bahwa literasi dini termasuk dalam kemampuan membaca dan menulis.

Pengertian perpustakaan sendiri berubah sejalan dengan perkembangan zaman. Umumnya, setiap terdapat kumpulan buku yang dikelola secara rapi dan teratur, bisa disebut perpustakaan. Menurut Basuki (2003) perpustakaan adalah sebuah gedung yang digunakan untuk menyimpan buku dan terbitan yang disimpan menurut susunan 
tertentu. Undang-Undang Nomor 20 Tahun 2003 menyebutkan bahwa perpustakaan meupakan sarana penunjang proses belajar mengajar di sekolah. Keberadaan perpustakaan sebagai salah satu komponen pendidikan merupakan suatu keharusan. Perpustakaan adalah salah satu sarana penunjang proses pendidikan. Darmono (2007) mengungkapkan bahwa perpustakaan berfungsi tidak hanya sebagai sumber informasi, melainkan dapat sebagai sarana pengembangan kreatifitas, karkter, dan hiburan. Sehingga dapat disimpulkan bahwa, perpustakaan adalah tempat untuk mencari, mengembangkan informasi, sekaligus sebagai sarana edukatif dimana mewujudkan perpustakaan yang aktif dan mandiri dalam menyelenggarakan pendidikan dalam menyediakan sumber-sumber informasi akurat. Perpustakaan adalah sebagai bentuk wujud kepedulian pemerintah dan masyrakat terhadap generasi-generasi penerus. Saepudin (2017) menyatakan bahwa, berseminya budaya baca adalah kebiasaan membaca, sedangkan kebiasaan membaca terpelihara dengan tersedianya bahan bacaan yang baik, menarik, memadai, baik jenis, jumlah maupun mutunya dan tidak ketinggalan dukungan dari pemerintah maupun masyarakat di daerah. Literasi merupakan gerakan sosial dengan dukungan kolaboratif dari berbagai elemen, upaya yang ditempuh untuk mewujudkannya berupa pengenalan, pembiasaan dan pembudayaan membaca pada anak-anak sejak dini.

\section{METODE}

Pengambilan data dilakukan di wilayah Kabupaten Bantul yang terfokuskan di Perpustakaan Umum Daerah Kabupaten Bantul, beralamatkan di Jalan Jendral Sudirman 1 Bantul. Penelitian berlangsung selama bulan Januari-Mei 2018. Subjek penelitian adalah anak pra sekolah yang mengikuti program literasi di perpustakaan umum Kabupaten Bantul yang didampingi guru dan orang tua, selain itu juga orang tua anak-anak pra sekolah yang mengunjungi pojok baca.

Jenis penelitian ini menggunakan pendekatan kualitatif studi kasus. Teknik pengumpulan data dilakukan melalui wawancara, obesrvasi, dan dokumentasi dari beberapa program literasi yang dimunculkan oleh Dinas Perpustakaan dan Kearsipan Kabupaten Bantul. Sumber data diperoleh dari informan, narasumber, dan partisipan adalah orang tua dan guru dari anak TK yang berkunjung ke perpustakaan, dan pengelola perpustakaan. Analisis data kualitatif menggunakan pengumpulan data, reduksi data, penyajian data dan simpulan.

\section{HASIL DAN PEMBAHASAN}

Launchingnya Bantul Literasi pada tanggal 13 Juni 2017 membuat Dinas Perpustakaan dan Kearsiapan menginovasi program literasi dengan memunculkan program literasi "OPERA MALAM BALI" yang mana singkatan dari Optimalisasi Peran Masyarakat Dalam Mewujudkan Bantul Literasi. OPERA MALAM BALI memuat beberapa program literasi yang salah satunya terfokus pada anak usia dini. Programprogram tersebut meliputi kunjungan anak pra sekolah ke perpustakaan untuk membaca buku, menonton film edukasi, dan workshop menulis dari KPCB (Komunitas Penulis Cilik Bantul). Dari program tersebut di harapkan agar masyarakat Kabupaten Bantul terlebih orang tua dan guru anak-anak pra sekolah mengetahui bahwa Perpustakaan Kabupaten Bantul saat ini sedang berusaha untuk memakmurkan masyarakat dengan memfasilitasi sebaik mungkin dengan harapan anak-anak di Kabupaten Bantul menajdi generasi yang literat dan dapat berpikir secara kritis.

Setelah launchingnya Bantul Literasi dengan program "OPERA MALAM BALI" angka pemustaka naik dari tahun sebelumnya, dimana pada tahun 2016 sekitar 24.000 orang telah menjadi anggota tetap perpustakaan. Dalam kurun waktu satu tahun pada tahun 2016 setidaknya ada 345.368 orang pemustaka (selain anak PAUD) yang berkunjung di perpustakaan, untuk kategori Anak Usia Dini (AUD) pada tahun 2016 hanya berkisar 2.880 anak yang berkunjung ke perpustakaan umum kabupaten. Pada tahun 
2017 setidaknya bertambah menjadi 518.693 pemustaka yang berkunjung, atau naik lima puluh persen (50\%). Pemustaka kategori anak usia dini pada tahun 2016 ada 2.880 anak dan pada tahun 2017 ada 4.320 dengan demikian pemustaka kategori anak usia dini naik lima puluh persen (50\%) dari tahun sebelumnya. Adapun mengenai jumlah yang menjadi anggota tetap perpustakaan untuk tahun 2017 bertambah menjadi 28.029 orang anggota.

Program literasi yang dibuat oleh Dinas Perpustakaan dan Kearsipan mendapat tanggapan positif dan dukungan dari seluruh lapisan masyarakat. Orang tua dan guru, bahkan anak pra sekolah sangat antusias ketika sedang berkegiatan literasi di Perpustakaan Daerah. Program literasi untuk anak usia dini meliputi: 1) Kunjungan Perpustakaan dan membaca di Ruang Baca Anak. Anak pra sekolah yang berkunjung ke perpustakaan adalah untuk pengenalan program literasi. Literasi untuk anak usia dini sendiri adalah proses pembelajaran baca dan tulis. Minat literasi dasar anak usia dini adalah kesenangan atau kecenderenungan seorang anak usia dini dalam kegiatan literasi. Terbentuknya minat literasi dasar anak usia dini tidak dapat terjadi dalam waktu singkat, tetapi pembentukan itu karena pembiasaan, mengenalkan dan membelajarkan anak literasi dalam kehidupan sehari-hari. Senada dengan penelitian Nutbrown \& Claugh (2015) bahwa pengenalan literasi bagi anak sangat penting dan sudah dilakukan sejak tahun 1980 karena melihat pentingnya mengenalkan atau membelajarkan literasi membaca dan menulis bagi anak usia dini.

Setelah adanya program literasi, anak gemar membaca meningkat dengan bertambahnya pemustaka anak usia dini di Perpustakaan Daerah. 2) Pemutaran Film. Anak belajar membaca di perpustakaan termasuk salah satu proses belajar diluar sekolah, dengan tujuan untuk melatih kemampuan berbicara dan menambah pembendaharaan kosa kata. Suyadi (2010) berpendapat bahwa anak mengembangkan kemampuan membaca dengan cara yang menakjubkan. Selain kemampuan literasi anak usia dini yang mencakup kemampuan membaca dan menulis, juga mencakup kemampuan berbicara dan menyimak. Sependapat dengan Whitehead (2004) literasi anak merupakan kemampuan yang berkaitan dengan membaca, menulis, menyimak, berbicara. Pemutaran film membuat anak mengasah kemampuan literasi menyimak dan berbicara, pasalnya setelah pemutaran film, anak diharapkan mampu menyampaikan kembali pesan moral yang terdapat dalam film. Secara tidak langsung anak dapat melatih rasa percaya diri hanya dengan berbicara di depan umum. Selesai kegiatan membaca buku di ruang baca anak kembali mencritakan apa saja yang sudah dilakukan, anak menceritakan di depan temanteman lain dan guru. 3) Workshop Menulis. Workshop menulis adalah program literasi yang bekerjasama dengan Komunitas Penulis Cilik Bantul (KPCB) program tersebut secara tidak langsung dapat mengembangkan kemampuan menulis anak. Workshop diadakan guna menjaring anak-anak dengan kemampuan istimewa yang nantinya dapat melahirkan generasi penulis berbakat dan menghasilkan karya. Kemampuan menulis anak usia dini tidak boleh berpusat pada pembenahan tulisan, melainkan susunan huruf menjadi kata barulah kata menjadi kalimat. Hal ini wajar karena pada dasarnya anak baru bisa memegang pensil. Nutbrown \& Clough (2015) mengemukakan bahwa kemampuan menulis pada anak usia dini termasuk proses untuk menghasilkan lambang bunyi. Anak menulis kata dengan cara yang sesuai dengan bunyi huruf, anak mampu menuliskan sebuah kata menjadi sebuah kalimat.

Karenanya, literasi anak usia dini setidaknya memerlukan serangkaian kemampuan berbahasa, kognitif, sosial emosional, bahkan pengetahuan berbudaya. Oleh karenanya, pengenalan literasi sejak dini diperlukan guna mengasah kecerdasan anak sedini mungkin, menambah pengetahuan anak dimana nantinya bisa membantu anak setelah memasuki tingkat pendidikan selanjutnya. Pengenalan literasi pada anak usia dini adalah suatu proses aktivitas yang memperkenalkan kemampuan membaca, menulis, berbicara, berpikir kritis pada anak usia dini tanpa adanya intimidasi dan 
paksaan. Pengenalan literasi pada anak usia dini dapat dilakukan dengan cara yang menyenangkan, sehingga anak tidak merasa bosan untuk mempelajari sesuatu hal yang baru.

\section{SIMPULAN}

Berdasarkan hasil analisis data yang dilakukan bahwa ketiga program literasi yang fokus pada anak pra sekolah berhasil secara bertahap, hingga mampu mendambah daftar jumlah pemustaka anak pra sekolah yang berkunjung ke perpustakaan dan membaca di perpustakaan. Lebih lagi, adanya program pemutaran film yang menjadi daya tarik tersendiri bagi anak-anak pra sekolah juga guru dan orangtua. Walaupun tidak semua anak langsung instan gemar membaca buku namun setidaknya anak merasa senang membaca buku dan tidak merasa bosan berkunjung ke perpustakaan. Program workshop menulis juga tidak kalah peminat, orangtua ataupun guru yang menginginkan anak bisa menulis dan menghasilkan suatu karya, tidak melewatkan kesempatan untuk mengikutsertakan anak dalam kegiatan literasi yang satu ini. Pengenalan literasi awalan untuk anak jauh lebih baik dilakukan sejak usia dini, dengan harapan kelak saat anak sudah dewasa mampu menerapkan apa yang sudah diperoleh sejak kecil dan memiliki rasa kecintaan terhadap membaca.

\section{DAFTAR PUSTAKA}

Abidin, Y., Mulyati, T., \& Yunansah, H. (2017). Pembelajaran Literasi. Jakarta: Bumi Aksara

Amariana, Ainin. (2012). Keterlibatan Orang Tua dalam Perkembangan Literasi Anak Usia Dini. Naskah Publikasi, HIm 9. Diperoleh pada 13 Januari, dari http://eprints.ums.ac.id/20334/13/NASKAH_PUBLIKASI.pdf

Andriani, Faricha. (2017). Peran Guru dan Orang Tua dalam Mengembangkan Literasi Anak Usia Dini. Naskah Publikasi, 6-8. Diperoleh pada 17 Januari, dari http://eprints.ums.ac.id/54223/12/NASKAH\%20PUBLIKASI.pdf.

Basuki, S. (2003). Manajemen Arsip Dinamis. Jakarta: Gramedia Pustaka

Beaty, J.J. (2013). Perkembangan Anak Usia Dini Edisi ke-7. Jakarta: Kencana Group

Cahyani, I.R. (2015). Peran Orang Tua dan Guru dalam Mengembangkan Literasi Dini (Early Literacy) Di Kabupaten Sidoharjo. Universitas Airlangga. Skripsi.

Darmono. (2007). Perpustakaan Sekolah: Pendekatan Satu Aspek Manajemen dan Tata Kerja. Jakarta: Gramedia Widiasmara Indonesia.

Enggelbetus. (2016). Urgensi Pengenalan Literasi bagi AUD. Universitas Negeri Surabaya. Skripsi.

Kern, R. (2000). Literacy and Language Teaching. Oxford: Oxford University Press.

Morrison, S.G. (2012). Dasar-Dasar Pendidikan Anak Usia Dini. Jakarta: PT Indeks

Nutbrown, Cathy., \& Clough, Peter. (2015). Pendidikan Anak Usia Dini, Sejarah, Filosofi dan Pengalaman.Yogyakarta: Pustaka Belajar

Reese, L. dkk. (2000). Longitudinal analysis of the antecedents of emergent Spanish literacy and Middle-School English reading achievement of Spanish-Speaking students, American Educational Research Journal Fall 2000, Vol. 3 7, No. 3, PP. 633-662

Saepudin, E., Sukaesih., \& Rusmana, A. (2017). Peran Taman Bacaan Masyarakat Bagi Anak Usia Dini. Jurnal Kajian Informasi \& Perpustakaan, Vol.V/No.1, Juni 2017, hlm. 1-12. Diperoleh pada 17 Januari 2018, dari http://jurnal.unpad.ac.id/jkip.

Susanto, Ahmad. (2017). Pendidikan Anak Usia Dini. Jakarta: Bumi Aksara.

Suyadi. (2010). Psikologi Belajar PAUD. Jogjakarta: Pedagogia.

Whitehead, M. (2004). Children"s Early Literacy. London. SAGE Publications Company 